\title{
An Impact of Budgetary Goal Characteristics on Performance: The Case of Vietnamese SMEs*
}

\author{
Thang Ngoc LE ${ }^{1}$, Dung Duc NGUYEN²
}

Received: July 03, 2020 Revised: July 19, 2020 Accepted: August 10, 2020

\begin{abstract}
The paper aims to investigate the impact of budgetary goal on profit growth directly and indirectly through managerial performance. Two main characteristics of budgetary goal mentioning in the study are the clarity of budget goal and the difficult of budget goal. Data of the research collected from survey with 197 department managers and supervisors of 80 SMEs in Hanoi and Ho Chi Minh City who have budgeting responsible. Firstly, by using quantitative research method Cronbach's Alpha and Exploratory Factor Analysis, the research show that characteristic of budgetary goal has significant and positive impact on profit growth directly. Secondly, the regression analysis among variables show that budget goal clarity was positively and significantly related to growth of sale revenue, growth of profit and managerial performance. Therefore, the empirical findings show that that managerial performance has mediating role in the relationship between budgetary goal characteristic and financial performance. The findings of this study suggest that that managers need focus on setting clearer and more difficult but attainable budget goals to increase firm performance. This paper also provides a new insight the relationship between managerial performance and financial performance. Budgetary goal characteristics still have positive but insignificant impact on growth of sales revenue.
\end{abstract}

Keywords: Budgetary Goals, Firm Performance, Financial Performance, Managerial Performance, SMEs.

JEL Classification Code: D22, D80, G11, G40, G41

\section{Introduction}

Currently, small and medium-sized enterprises (SMEs) are accounting for about $98 \%$ of total number of enterprises in Vietnam. Each year, SMEs create over one million new jobs, utilize up to $51 \%$ of labor force in the society, and contribute more than $40 \%$ of GDP to the country. Though

\footnotetext{
*Acknowledgements:

This research is funded by the National Economics University (NEU), Hanoi, Vietnam. The authors thank anonymous referees for their contributions and the NEU for funding this research.

${ }^{1}$ First Author. Lecturer, School of Accounting and Auditing, National Economics University, Vietnam. Email: thangkt47d@gmail.com ${ }^{2}$ Corresponding Author. Lecturer, School of Accounting and Auditing, National Economics University, Vietnam [Postal Address: 207 Giai Phong Road, Dong Tam Ward, Hai Ba Trung District, Hanoi, 113068, Vietnam] Email: dungnd2141@gmail.com Non-Commercial License (https://creativecommons.org/licenses/by-nc/4.0/) which permits unrestricted non-commercial use, distribution, and reproduction in any medium, provided the original work is properly cited.
}

there is a significant number of SMEs, most of them operate on a small scale and have a low level of development. Given the current situation, the research on management tools in Vietnamese SEMs has great significance in terms of both theoretical as well as practical application. The budget is known as an effective tool in the planning and control of production and business activities, thereby improving firm performance (Garrison, 2003). In this case, budgetary goal is not only a performance measurement, but conversely also a factor affecting manager's motivation. According to Locke's goal setting theory, characteristics of budgetary goals can create employees motivation and improve performance. In fact, many researcher prove that the clarity of budgetary goals has positive impact on the performance but they still failed to provide the solid evidence for the positive relationship between the difficulty of budgetary goals and performance. For instance, he reported that the difficulty of budgetary goals do not directly impact on cost efficiency in US manufacturing companies. Besides, the contingency approach indicates that all result may vary depending on the change of contingency factors such as context research, variable measurement, etc. This paper still examines the 
relationship between budgetary goal characteristic and the firm performance but I will focus on the intermediate role of managerial performance in the research model. The sections in this essay include introduction, literature review, data and research method, results and discussion and conclusion.

\section{Literature Review}

According to Hirst and Lowy (1990), budgets are an effective tools used in administration activities with two basic functions: planning and controlling. Planning function of budget help managers to concretize the goals that need to be achieved. Therefore, the characteristic of budgetary goals have a great influence on performance. The relationship between budgetary goal characteristic and performance has been shown in many previous studies such as Kren (1992).

\subsection{Locke's Goal-Setting Theory in Firm Budgeting}

The budget is not only a planning and controlling tool but also motivates employees through setting appropriate goals. Setting goals is a way to create motivation for both individuals and organizations. In fact the goal setting theory has been recognized as one of the most valuable and useful motivational theories in psychology and organization. The theory of goal setting was proposed by Locke (1968). Locke found that generic motivations are less effective than incentives with specific goals. The study of him was also shown that the link between setting a difficult goal will create greater motivation than an easy goal because every individual needs to express themselves. Based on this, he suggested that the clarity and difficulty are the two of most important characteristics of goal to create motivation for employees thereby improving firm performance. Developing the theory, Locke and Latham (1991) added three more factors to ensure the success of goal setting: commitment, feedback and complexity. So they suggested five characteristic of goals that affect employee motivation.

- Clarity: When a goal is clear it's easy to understand exactly what employee need to achieve. The clarity of the goal is the guarantee for the success of the implementation that goal thereby creating the motivation for the person to achieve the goal. Conversely, when a goal is vague and imprecise, it is difficult to know and achieved it. Locke and Latham (1991) defined the clarity of goals in five aspects, including: Specific, Measurable, Achievable, Relevant and Time-bound. In which, relevant aspect means employee must understand the important of the goals which they have responsible for the organization.

- Challenge: To motivating goals need to be challenging, but not too challenging. A goal too easy to achieve will not create employees motivation and increase their performance.
But the goal that employees perceive as way beyond your capability will not motive them either. For a goal to motivate it must hit the sweet spot between challenge but not over challenge. In another way, the challenge of goals is also known the difficulty of goals.

- Commitment: The commitment is expressed by the degree to which employees believe that they can accomplish their goals. In fact, employees only commit to their goals when they are involved in setting that goal. In the studies on the budget goal characteristic, the commitment is very close to budget participation, one of the factors influencing employee motivation and firm performance.

- Feedback: In order for setting the goal continue to motive employees as their work towards it, they must receive feedback. Feedback allows them to know that their efforts are appreciated. This should improve their performance.

- Complexity: A complexity goal is the goal which has too many interconnected parts to form an coherent whole. The problem comes when a goal is too complex and the team member becomes confused about how best to achieve the goal. These feelings then result in poor motivation and often people resist and can even obstruct attaining the goal.

This paper will apply Locke and Latham's goal setting theory to explain the impact of budget goal characteristic on firm performance. In which, Authors focus on two main characteristics: Budget goal clarity and Budget goal difficulty.

\subsection{The Impact of Budget Goal Characteristic on Firm Performance}

\subsubsection{Budget Goal Clarity}

According Locke's goal-setting theory, employees want to achieve target, where with clearer goals it will be easier. Most studies agree that performance will increase if the budgetary goals are clearer. For example, Kenis (1979) shows a positive relationship between the clarity of budget goals and performance. The clarity of the budget goals is expressed by the department manager's level of awareness of the goals assigned by the superior. It includes clarity on goal content and goal priority. He also suggested that managers achieve their goals easier if the budgetary goals are more clearer. This results is based on the questionnaire survey 169 department managers at the plant level who have budget responsibility in New Jersey manufacturing enterprises. By linear regression method, the research result show that the clarity of budget goals has positive impact on budgetary performance and cost efficiency. The result also show the positive effects from budget goal clarity to job satisfaction and budget motivation. Using the similar approach, few studies such as Qi (2010); Nguyen and Nguyen (2019); and Lestari et al. (2020) also found the positive relationship 
between the clarity of budget goals and the performance of businesses in other aspects such as financial performance, management performance. They used contingency theory to explain. A contingency theory is an organizational theory that claims that there is no best way to organize a corporation, to lead a company, or to make decisions.

Qi (2010) conducted on 75 SMEs (Small and medium enterprise) in China shown that budget goal clarity has positive effect on job satisfaction and goal achievement. Qi's study also uncovers the controlling role of firm's size and ownership form. Profitable firms sometimes attempt to push up the stock price by excessively increasing debt over its optimal level and mislead the market to believe in its inflated growth opportunity in the future. Indeed, they believe that the extra cost of issuing debts shall prevent less profitable firms from taking advantages of higher leverage as compared to those with better performance, despite the managers' attempt to fool the public.

The state owned enterprise show the higher job satisfaction than the private firm. Also studying the characteristics of budget goal characteristic in SMEs. Mulani, Chi and Yang (2015) found a positive relationship between the clarity of budget goals and firm performance on the financial aspect. Based on 268 questionnaires collected from SMEs of India, the result of them research add to the fact that higher sale growth and profit growth can be achieve through more clear budgetary goals. They has added the growth rate of revenue and the profit growth rate when measuring the performance of each relationship with the clarity of the estimation goal. 68 small-scale enterprises in India showed that the higher the clarity of the estimation target, the growth rate of revenue and profit growth rate of enterprises. the bigger the karma. Meanwhile, they uses a return on total assets (ROA) when measuring the performance of businesses on financial aspects and also finds a positive relationship with the clarity of goal. It can be said that the clarity and understandability of the budgetary goals is one of the decisive factors for the performance of managers and enterprises. As the review of literature show that the clarity of budget goal have a sign impact on firm performance, so the hypothesis of this article are:

H1a: The clearer budget goals the better managerial performance;

H1b: The clearer budget goals the higher growth of sales revenue;

H1c: The clearer budget goals the higher growth of profit.

\subsubsection{Budget Goal Difficulty}

Budget is not only the planning tool but also the controlling tool, the evaluating tool and motivation tool for employees. Locke's goal-setting theory also said that a difficult but realistic goals can be more motivational than easy or extremely difficult ones. Specifically, managers would be appreciated if they fulfilled or outperformed budgetary goals. By this way, budgetary goal become the factor which create the employees motivation. Budget goals can be set from very easily attainable to very unattainable. In some ways, the assessment based on the budget will create pressure on the work of manager. If the budget goals are set too hard, it will cause dissatisfaction among the managers and thus reduce the business performance.

On the contrary, if budgetary goals are set too easily, managers will feel more comfortable with their work but also lessen their motivation. He also suggested that budget goals are difficult to create pressure for managers but also motivate them and the budget goals are difficult but achievable will increase firm performance. However, the study only found the positive relationship between budget goal difficulty and budgetary motivation while the budget goal difficulty has negative effect on budgetary performance. In fact, several studies can not provide clear evidence. On another way, their study also can not find the direct effects from the difficulty of budget goal to budgetary performance but they find the indirect effects through budgetary feedback. Different from Kenis (1979), Hirst and Lowy (1990) used managerial performance instead of budgetary performance in the model research. More recently study also found the negative relationship between budget goal difficulty and profit growth. But they could not find a significant relationship between budget goal difficulty and sales growth. Thus, the budgetary goals need not only be clear, but also be suitable level of difficulty. In short, the clarity, and difficulty are two main characteristic of budgetary goals that influence the performance of manager and performance of enterprises. Hence it can be inferred from this study that more difficult and attainable budget goals tend to motivate mangers to higher performance.

H2a: The more difficult but attainable budget goals the better managerial performance;

$\boldsymbol{H} \mathbf{2 b}$ : The more difficult but attainable budget goals the higher growth of sales revenue;

H2c: The more difficult but attainable budget goals the higher growth of profit.

\subsection{The Relationship between Managerial Performance and Firm Performance}

Performance is a complex concept and it can be measure by many different methods. In general, performance is understood as the degree to which an individual or an organization achieves the goals. For an enterprise in particular, performance is normally measured by the final 
result in term of financial aspect or nonfinancial aspect such as profit, revenue, customer satisfaction. But in fact, the firm performance can not be separated from the individual performance such as the managers in business. Thus, it is clear to see that there is a connection between firm performance and the performance of managers which is call managerial performance. According to Mahoney et al. (1963), managerial performance is the result of a series of activities that represent the function of management, including: planning, evaluating, coordinating, communicating, investigating, staffing, negotiating and representing. Mahoney et al. (1963) also suggest that the manager's performance can be measured based on the level of implementation of these activities. Following that, the level of implementation of these activities directly affect the performance of the division which the managers has responsibility. Therefore, managerial performance is used to measure firm performance in many previous studies such as Kren (1992); Qi (2010); Huynh and Nguyen (2019); and An and Kim (2019). However managers at different levels often focus on different activities so managerial performance can not be expressed directly by the final result of the departments. Therefore, managerial performance must be measured by Likert scale like Mahoney research in 1963. Mahoney et al. (1963) asked 452 managers from 13 companies to rate their own perceived performance on eight sub-dimensions of managerial performance presented above.

In contrast, firm performance measurements are built quite specific and constantly developed over time. Initially, the performance of an enterprise is primarily measured on financial scales such as revenue and profit because it is associated with the ultimate goal of business operations to maximize property of the owners. However, with changes in the business environment and the increase in the level of competition among businesses, the performance of enterprises is measured more comprehensively on both financial and non-financial aspects. Kaplan and Norton (1990) introduced a balanced scorecard model to measure firm performance more comprehensively with four aspects of finance, customers, internal processes, learning and development. Lynch and Cross (1995) also presented a pyramid model to measure business performance of enterprises on many more aspects from the short term to the long term.

According to Herciu (2010), managerial performance has a strong correlation with firm performance. Achieving a specific goal is the best way for managers to show managerial performance. Based on agency theory, Herciu (2010) explained that management should be held accountable for their firm's performance and they should be replaced when the performance is poor. Agency theory is a management and economic theory that attempts to explain relationships and self-interest in business organizations. There is a conflict of objectives between two parties because of the existence of asymmetric information. Agency relationship is the cause of information asymmetry between the principal and the agent. However, the conflict of goals can be appear when firm's shareholders and their managers have different purpose (Amacha \& Dastane, 2017, Dao \& Ta, 2020). Moreover, the relationship between managerial performance and firm performance is still not proved by statistical test. This study will explore the positive relationship between managerial performance and firm performance in financial term. Hence, hypothesis $\mathrm{H} 3$ is proposed as follows:

H3a: The better managerial performance the higher growth of sales revenue.

H3b: The better managerial performance the higher growth of profit.

\section{Data and Research Methods}

\subsection{Data Collection}

The study employ a survey method to collect data. A sample of the study consisted department managers and supervisors of 80 SMEs in Hanoi and Ho Chi Minh city. To obtain survey data of 197 responses, 302 questionnaires are distributed to the managers who have budgeting responsible. Quantitative research data was collected based on the convenient distribution. Because the questionnaires were sent indirect to managers through the city treasuries and city tax departments, respondents must confirm whether they are responsible for the budget or not. In 197 questionnaires were returned, 197 questionnaires are usable for analysis (a 65 percent response rate). Twenty three percent of the respondents report holding master degree, the rest have university degree. The female managers hold $36 \%$ of the respondents. All respondents reported that they have over 4.7 years experience in budgeting. The companies represented in the sample were in services, commerce, construction and manufacturing. The sample size is enough for testing Cronbach's Alpha, Exploratory Factor Analysis and Linear Regression (Hair et al., 2006).

The minimum sample size is calculated as follows: $\mathrm{N}=5^{*} \mathrm{~m}=5^{*} 18=90<197$ (therein: $\mathrm{N}$ sample size; $\mathrm{m}$ : the number of items)

\subsection{Research Methods}

\subsubsection{Measurements of Budgetary Goal Characteristics}

Eight Likert types questionnaire item, scored from one to five, were used to measure budget goal characteristics. All items of the measurement were inherited from Kenis 
measurement which included 05 items measuring the difficulty of budget goals and 03 items measuring the clarity of budget goals; the descriptions of the questionnaire items are presented:

Budget goal clarity

1. I know very clearly and specifically about my budget goals

2. I think my budget goals are vague and unclear.

3. I realize clearly the importance and the priority order of each budget goal.

Budget goal difficulty

1. I easily achieved my budget goals.

2. My budget goals are quite hard to achieve.

3. My budget goals require a lot of knowledge and high skills to achieve

4. I must effort to achieve my budget goals

5. Overall, how would you rate the difficulty of your budget goals?

Cronbach's Alpha test was applied to check the reliability of the budget goal characteristic scales.
Both scales ensured the reliability with Cronbach's Alpha coefficient $>0.6$ and total correlation coefficient $>0.3$ (Hair et al., 2006).

\subsubsection{Measurements of Performance}

Performance variables in the model research were measured by two scales: Managerial performance measurement (Mahoney et al., 1963) and financial performance measurement (Mulani, Chi, \& Yang, 2015). Managerial performance measurement includes 8 items suggested by Mahoney (1963) and they were measured by self-rate of managers from very low (1) to very high (5). Financial performance is measured by 2 items inherited from the study of Mulani, Chi and Yang (2015). The growth of sale revenue and the growth of profit. These items were compared to the average of General Statistics Office of Vietnam (GSO) by respondents. Where by the growth of sale revenue and the growth of profit were scored from much lower (1) to much higher (5). The reliability of both performance measurements were also ensured by Cronbach's Alpha test. The results were shown in Table 1 and in the table the variables were code according to the abbreviations of their name.

Table 1: Cronbach's Alpha coefficient

\begin{tabular}{|c|c|c|c|c|c|c|}
\hline \multicolumn{5}{|c|}{ Item - Total statistic } & \multicolumn{2}{|c|}{ Reliability Statistics } \\
\hline & $\begin{array}{l}\text { Scale Mean if } \\
\text { Item Deleted }\end{array}$ & $\begin{array}{l}\text { Scale Variance } \\
\text { if Item Deleted }\end{array}$ & $\begin{array}{l}\text { Corrected Item- } \\
\text { Total Correlation }\end{array}$ & $\begin{array}{c}\text { Cronbach's Alpha if } \\
\text { Item Deleted }\end{array}$ & Cronbach's Alpha & $\mathrm{N}$ of Items \\
\hline \multicolumn{7}{|c|}{ BD (Budget goal Difficulty) } \\
\hline BD1 & 15.77 & 3.310 & .537 & .818 & \multirow{5}{*}{.827} & \multirow{5}{*}{5} \\
\hline BD2 & 15.73 & 3.455 & .646 & .791 & & \\
\hline BD3 & 15.65 & 3.023 & .651 & .786 & & \\
\hline BD4 & 15.73 & 3.300 & .645 & .788 & & \\
\hline BD5 & 15.61 & 2.993 & .667 & .780 & & \\
\hline \multicolumn{7}{|c|}{ BC (Budget goal Clarity) } \\
\hline $\mathrm{BC} 1$ & 7.26 & 2.621 & .742 & .723 & \multirow{3}{*}{.834} & \multirow{3}{*}{3} \\
\hline $\mathrm{BC} 2$ & 7.39 & 2.709 & .640 & .824 & & \\
\hline BC3 & 7.08 & 2.652 & .703 & .760 & & \\
\hline \multicolumn{7}{|c|}{ MP (Managerial Performance) } \\
\hline MP1 & 25.71 & 12.290 & .634 & .874 & \multirow{8}{*}{.886} & \multirow{8}{*}{8} \\
\hline MP2 & 25.69 & 11.950 & .700 & .867 & & \\
\hline MP3 & 25.60 & 11.905 & .703 & .867 & & \\
\hline MP4 & 25.71 & 12.525 & .636 & .873 & & \\
\hline MP5 & 25.67 & 12.375 & .695 & .868 & & \\
\hline MP6 & 25.53 & 11.995 & .704 & .866 & & \\
\hline MP7 & 25.67 & 12.702 & .612 & .876 & & \\
\hline MP8 & 25.70 & 12.435 & .568 & .881 & & \\
\hline
\end{tabular}


Because the scales were adapted to the new research context of Vietnamese SMEs, the exploratory factor analysis was applied to assess the degree of discrimination of the scales. With exploratory factor analysis, KMO coefficients range from 0.5 to 1.0 and $\mathrm{Sig}<0.05$, showing that the factors are not correlated with each other and factor analysis is consistent with the data collected. Four factors with eigenvalue greater than one are extracted and these factors accounted approximately for 65 percent of common variance of the 18 items including the items of dependent variables. The initial principal component matrix was rotated (Varimax) to reach a final solution. The Varimax-rotated component matrix is presented in Table 2 and Table 3.

Table 2: KMO coefficient and Bartlett test

\begin{tabular}{|l|c|c|}
\hline \multicolumn{2}{|l|}{ KMO and Bartlett's Test } \\
\hline $\begin{array}{l}\text { Kaiser-Meyer-Olkin Measure of } \\
\text { Sampling Adequacy. }\end{array}$ & .843 \\
\hline $\begin{array}{l}\text { Bartlett's } \\
\text { Test of }\end{array}$ & Approx. Chi-Square & 1585.394 \\
\cline { 2 - 3 } Sphericity & df & 153 \\
\cline { 2 - 3 } & Sig. & .000 \\
\hline
\end{tabular}

Table 3: Rotated Component Matrix

\begin{tabular}{|l|c|c|c|c|}
\hline \multirow{2}{*}{} & \multicolumn{4}{|c|}{ Component } \\
\cline { 2 - 5 } & $\mathbf{1}$ & $\mathbf{2}$ & $\mathbf{3}$ & $\mathbf{4}$ \\
\hline MP6 & .780 & & & \\
\hline MP2 & .758 & & & \\
\hline MP1 & .743 & & & \\
\hline MP5 & .724 & & & \\
\hline MP7 & .722 & & & \\
\hline MP4 & .719 & & & \\
\hline MP8 & .703 & & & \\
\hline BD4 & .631 & & & \\
\hline BD2 & & .783 & & \\
\hline BD3 & & .781 & & \\
\hline BD5 & & .773 & & \\
\hline BD1 & & .772 & & \\
\hline BC1 & & .665 & & \\
\hline BC3 & & & .888 & \\
\hline BC2 & & & .844 & \\
\hline FP1 & & & .806 & \\
\hline FP2 & & & & .884 \\
\hline
\end{tabular}

Thus all variable measurements were inherited from previous studies and they are synthesized in table 4 . After testing the reliability of variable measurements, the hypotheses of the study were tested by using Linear regression analysis. T-statistics were used to test the significance level of regression coefficient and F-values were used to test significance level of the overall regressions. The percentage of variation of the dependent variables explained by independent variables was represented by $\mathrm{R}^{2}$ - adjusted. Quantitative research using linear regression model processed by SPSS software version 25.0. All variables are measured by inheriting scales from previous studies. Variable of Characteristics of budgetary goal (BG) include 03 item measure the clarity of budget goal and 05 item measure the difficulty of budget goal. Variable of managerial performance (MP) inheriting Mahoney scales. Financial performance include growth of sale revenue (FP1) and growth of profit (FP2)

\section{Results and Discussion}

The results obtained from testing the relationship between budget goal characteristic and performance were shown in Table 4 and Table 5. Based on the information in Table 5, the regression analysis among variables show that budget goal clarity was positively and significantly related to growth of sale revenue, growth of profit and managerial performance. The results succeed to support the Hypothesis $1(\mathrm{FP} 1$ at $\mathrm{Sig}=.010<.05, \mathrm{FP} 2$ at $\mathrm{Sig}=.00<.05$ and MP at Sig $=.002<.05$ ). The information in table 5 also supported Hypothesis 2 . Budget goal difficulty positively and significantly impacted on firm performance (FP1 at Sig $=.037<.05$, FP2 at Sig $=.00<.05$ and MP at Sig $=.000<.05)$. However, the R2 adjusted coefficients in all of three model are quite low. Therefore the variation of firm performance was explained very little by the clarity and difficulty of budget goal (R2 adjusted of model $1=.055$, $\mathrm{R} 2$ adjusted of model $2=.191, \mathrm{R} 2$ adjusted of model 3 $=.138$ ).

On another hand, with the involvement of managerial performance in the model, the relationship between budgetary goal characteristic and growth of sales revenue becomes insignificant. The result suggests that managerial performance has mediating role in the relationship between budgetary goal characteristic and financial performance. In this case, Hypothesis 1a and Hypothesis $2 \mathrm{a}$ are rejected. Detailed results are presented in Table 6. 
Table 4: Relationship between Budget goal characteristic and Performance

\begin{tabular}{|c|c|c|c|}
\hline \multirow{2}{*}{ Dependent variables } & \multirow{2}{*}{ Constant } & \multicolumn{2}{|c|}{ Independent variables } \\
\hline & & Budget goal clarity (BC) & Budget goal difficulty (BD) \\
\hline $\begin{array}{l}\text { Growth of sale revenue (FP1) } \\
\text { Standardized Coefficients Beta } \\
\text { t-value (at Sig.) } \\
\text { Adjusted R Square }\left(R^{2}=.055\right) \\
\text { F-value }\left(6.710^{*}\right)\end{array}$ & 1.409 & $\begin{array}{c}.183 \\
2.591(\text { at Sig. }=.010)\end{array}$ & $\begin{array}{c}.148 \\
.037 \text { (at Sig. }=.037)\end{array}$ \\
\hline $\begin{array}{l}\text { Growth of profit }(F P 2) \\
\text { Standardized Coefficients Beta } \\
\text { t-value } \\
\text { Adjusted R Square }\left(R^{2}=.191\right) \\
\text { F-value }\left(24.082^{*}\right)\end{array}$ & .002 & $\begin{array}{c}.324 \\
4.971 \text { (at Sig. }=.000)\end{array}$ & $\begin{array}{c}.255 \\
3.913 \text { (at Sig. }=.000)\end{array}$ \\
\hline $\begin{array}{l}\text { Managerial performance (MP) } \\
\text { Standardized Coefficients Beta } \\
\text { t-value } \\
\text { Adjusted R Square }\left(R^{2}=.138\right) \\
\text { F-value }\left(16.652^{*}\right)\end{array}$ & 1.902 & $\begin{array}{c}.209 \\
3.102 \text { (at Sig. }=.002)\end{array}$ & $\begin{array}{c}.287 \\
4.258(\text { at Sig. }=.000)\end{array}$ \\
\hline
\end{tabular}

* Significant at $<.05$ level

Table 5: Relationship between Managerial performance and financial performance

\begin{tabular}{|l|c|c|c|c|c|}
\hline & \multicolumn{5}{|c|}{ Managerial performance (MP) } \\
\hline & Constant & $\begin{array}{c}\text { Standardized } \\
\text { Coefficients Beta }\end{array}$ & $\mathbf{t}$-value & $\mathbf{R}^{2}$ adjusted & F-value \\
\hline Growth of sale revenue (FP1) & .993 & .363 & $5.435^{*}$ & .127 & $29.545^{*}$ \\
\hline Growth of profit (FP2) & .760 & .396 & $6.030^{*}$ & .153 & $36.358^{*}$ \\
\hline
\end{tabular}

* Significant at $<.05$ level

Table 6: The involvement of Managerial performance in the Relationship between Budget goal characteristic and Performance

\begin{tabular}{|c|c|c|c|c|}
\hline \multirow{2}{*}{ Dependent variables } & \multirow{2}{*}{ Constant } & \multicolumn{3}{|c|}{ Independent variables } \\
\hline & & BC & BD & MP \\
\hline $\begin{array}{l}\text { Growth of sale revenue (FP1) } \\
\text { Standardized Coefficients Beta } \\
\text { t-value (at Sig.) } \\
\text { Adjusted R Square }\left(R^{2}=.135\right) \\
\text { F-value }\left(11.233^{*}\right)\end{array}$ & .401 & $\begin{array}{c}.117 \\
1.695(\text { at Sig. }=.092)\end{array}$ & $\begin{array}{c}.058 \\
.828(\text { at Sig. }=.409)\end{array}$ & $\begin{array}{c}.314 \\
4.363 \text { (at Sig. }=.000)\end{array}$ \\
\hline $\begin{array}{l}\text { Growth of profit (FP2) } \\
\text { Standardized Coefficients Beta } \\
\text { t-value } \\
\text { Adjusted R Square }\left(R^{2}=.250\right) \\
\text { F-value }\left(22.722^{*}\right)\end{array}$ & -.892 & $\begin{array}{c}.268 \\
4.163 \text { (at Sig. }=.000)\end{array}$ & $\begin{array}{c}.178 \\
2.708 \text { (at Sig. }=.007)\end{array}$ & $\begin{array}{c}.270 \\
4.028(\text { at Sig. }=.000)\end{array}$ \\
\hline
\end{tabular}




\section{Conclusion}

The result presented above showed that the budgetary goal characteristics can have positive and significant impact on such growth of sales revenue, growth of profit and managerial performance. Based on these results, the study implied that managers need focus on setting clearer and more difficult but attainable budget goals to increase firm performance. This study also proves the relationship between managerial performance and financial performance as the prediction in several studies before. The higher managerial performance lead the better growth of profit and growth of sales revenue. This study also detects the mediating role of managerial performance when testing the relationship between budgetary goal characteristic and financial performance by adding managerial performance to the model. The result shows that budgetary goal characteristics still have positive but insignificant impact on growth of sales revenue. However, the mediating role of managerial performance has not tested in this study. Therefore, the limitation is the new research direction that can be supplement by subsequent studies. Moreover, this study only carried out on 197 SMEs, so they could not represent all Vietnamese enterprises in general. In addition, the $\mathrm{R}^{2}$ coefficient of the models in this research is relatively low, proving that not only the budget goal characteristics affect firm performance but also other features of budget. These research gaps also suggest the direction for the new research in the future.

\section{References}

An, H. J., \& Kim, W. K. (2019). A Case Study on the Influence Factors of Financial Performance of Korean Automotive Parts Cooperation Companies through Research Hypothesis. Journal of Asian Finance, Economics and Business, 6(3), 327-337. https://doi.org/10.13106/jafeb.2019.vol6.no3.327

Amacha, E. B., \& Dastane, O. (2017). Sustainability Practices as Determinants of Financial Performance: A Case of Malaysian Corporations. Journal of Asian Finance, Economics and Business, 4(2), 55-68. http://dx.doi.org/10.13106/jafeb.2017. vol4.no2.55

Dao, B. T. T., \& Ta, T. D. N. (2020). A meta-analysis: capital structure and firm performance. Journal of Economics and Development, 22(1), 111-129. DOI: 10.1108/JED-12-20190072.

Garrison, R. H. (2003). Management Accounting (15th ed.). New York, NY: McGraw-Hill Education.

Hair, J. F., Anderson, R. E., Tatham, R. L., Babin, B., \& Black, B. (2006). Multivariate data analysis (6th ed.). Upper Saddle River, NJ: Prentice Hall.

Herciu, M. (2010). The relation between managerial performance and firm performance - Several considerations. Revista Economica, 49(1-2), 51-58.
Hirst, M. K., \& Lowy, S. M. (1990). The linear additive and interactive effects of budgetary goal difficulty and feedback on performance. Accounting Organizations and Society, 15(5), 425-446. https://doi.org/10.1016/0361-3682(90)90026-Q

Huynh, Q. L., \& Nguyen, N. V. (2019). The Effect of Prior Financial Performance on Organizational Reputation and Earnings Management. Journal of Asian Finance, Economics and Business, 6(4), 75-81. https://doi.org/10.13106/jafeb.2019. vol6.no4.75

Kaplan, R.S. (1991). New systems for measurement and control. Engineering Economist, 36(3), 201-218. https://doi. org/10.1080/00137919108903045

Kenis, I. (1979). Effects of budgetary goal characteristics on managerial attitudes and performance. The Accounting Review, 54(4), 707-721.

Kren, L. (1992). Budgetary participation and managerial performance: The impact of information and environmental volatility. The Accounting Review, 67(3), 511-526

Lestari, S. D., Leon, F. M., Widyastuti, S., Brabo, N. A., Putra, A. H. P. K. (2020). Antecedents and Consequences of Innovation and Business Strategy on Performance and Competitive Advantage of SMEs. Journal of Asian Finance, Economics and Business, 7(6), 365-378. https://doi.org/10.13106/jafeb.2020. vol7.no6.365

Locke, E. A. (1968). Toward a theory of task motivation and incentives. Organizational Behavior and Human Performance, 3(2), 157-189. https://doi.org/10.1016/0030-5073(68)90004-4

Locke, E. A., \& Latham, G. P. (1991). A Theory of Goal Setting and Task Performance, Organizational Behavior and Human Decision Processes, 50, 212-247.

Locke, E. A., \& Latham, G. P. (2002). Building a practically useful theory of goal setting and task motivation: A 35-year odyssey. American Psychologist, 57(9), 705-717. https://doi. org/10.1037/0003-066X.57.9.705

Lynch, R. L., \& Cross, K. F. (1995). Measure Up! Yardstick for Continuous Improvement (2nd ed.). Hoboken, NJ: Wiley.

Mahoney, T. A., Jerdee, T. H., \& Carrol, S. J. (1963). Development of Managerial Performance: A Research Approach. Cincinnati, $\mathrm{OH}$ : South-Western College Publishing.

Mulani, J., Chi, G., \& Yang, J. (2015). Effects of the budgetary process on SME's performance: An Exploratory study based on Selected SME's in India. Research Journal of Finance and Accounting, 6(14), 135-153.

Nguyen, L. T. N., \& Nguyen, C. V. (2020). The Determinants of Profitability in Listed Enterprises: A Study from Vietnamese Stock Exchange. Journal of Asian Finance, Economics and Business, 7(1), 47-58. https://doi.org/10.13106/jafeb.2020. vol7.no1.47

Qi, Y. (2010). The impact of the Budgeting Process on Performance of SMEs in China. Doctoral Dissertation. Enschede, Netherlands: The University of Twente. 